\title{
INFLUENCE OF FERTILIZERS, MINOR ELEMENTS, AND SOIL pH ON THE GROWTH AND PROTEIN CONTENT OF TROPICAL KUDZU
}

\author{
P. Landrau, Jr., G. Samuels, and P. Rodriguez ${ }^{1}$
}

\section{INTRODUCTION}

There has been a long-time need for a vigorous legume in Puerto Rico, capable of being used for soil-erosion control and as a pasture and hay crop. One of the first projects of the Agricultural Experiment Station ${ }^{2}$ was the establishment of field experiments to study new legumes suitable for use in Puerto Rico. From this beginning the Station has been concerned with the task of finding suitable legumes for the farmers.

Many legumes have been tested, both native and imported. One of these, alfalfa (Medicago sativa), showed promise of providing a high-tonnage, highprotein legume for Puerto Rico. However, it proved susceptible to certain insect injury and its best growth was limited to those soils of $\mathrm{pH}$ above 6.5. The majority of these neutral to alkaline soils are found in the irrigated areas of the northwest and southern portions of the Island where there is insufficient rainfall to support the growth of this legume. The humid sections of the Island where the soil $\mathrm{pH}$ is normally below 5.5, still lacks a highprotein legume comparable to alfalfa.

Kudzu (Pueraria thunbergiana Benth.), which has done so well in the humid southeastern United States, has failed to grow satisfactorily under tropical conditions. With the introduction of tropical kudzu (Pueraria phaseoloides (javanica) Benth.), it appears that a legume suitable for the humid areas of Puerto Rico has been found.

Since its introduction in 1940, by the Soil Conservation Service, many conflicting observations have been reported concerning the growth habits, agronomic needs, $\mathrm{pH}$ tolerance, nutritional and soil requirements of tropical kudzu. Smith and Chandler $(4)^{3}$ reported that, on fertile land, a pH of 5.5 permitted near-maximum growth, and that phosphorus was the soil nutrient most likely to be deficient. However, the data presented showed that highest yields were made when phosphate was used with lime; and insufficient data were presented to tell whether the increase was attributable to the phosphate, or the lime, or a combination of both. Telford and Childers

${ }^{1}$ Assistant Agronomist, Plant Physiologist, and Associate Agronomist, respectively. Agricultural Experiment Station, University of Puerto Rico, Río Piedras, P. R. The authors wish to thank the following members of the staff for their help in the conduct of this work: A. Riera, R. Olivencia, H. Gandía-Díaz, and B. G. Capó.

2 Then called the Sugar Cane Experiment Station, 1912.

${ }^{3}$ Numbers in parentheses refer to Literature Cited, p. 95. 
(5) used a 10-10-5 complete fertilizer to establish kudzu in their field work. Samuels and Landrau (3), in greenhouse experiments, found that lime and nitrogen applications did increase kudzu yields.

In order to obtain a clear picture of the fertilizer requirements and $\mathrm{pH}$ demands of tropical kudzu, the Agronomy and Horticulture Department of the Agricultural Experiment Station initiated a study of the problem. This paper reports the findings of the work.

\section{PROCEDURES}

\section{Greenhouse $\mathrm{pH}$ Experiment}

The first investigation of the $\mathrm{pH}$ requirements of kudzu consisted of a greenhouse pot experiment. Using a Río Piedras clay with a natural $\mathrm{pH}$ of $5.2, \mathrm{pH}$ levels of $5.2,5.5,6.0,6.5,7.0$, and 7.5 were established, each level being replicated nine times. The soils were brought to the required $\mathrm{pH}$ levels by mixing in the proper quantity of $\mathrm{CaCO}_{3}$ as determined by the method of Riera (2). The soils were placed in 1-gallon Mitscherlich pots, innoculated, and then planted with kudzu, using three plants per pot. The tops were harvested six months after planting.

\section{Ceiba Field Experiment}

A fertilizer experiment using different levels of nitrogen, phosphorus, and potassium was conducted at the "Ceiba" field of the Agricultural Experiment Station at Río Piedras. The soil type used was classified as a Río Piedras clay, an acid plastic clay derived from shale (1). The crop was planted April 10, 1947, on 1/100-acre plots using seven replications per treatment. The treatments used are given later in table 2 . The experiment was harvested on October 15, 1947, at an age of 6 months.

\section{García-Méndez Field Experiment}

A fertilizer-lime experiment was carried out at the García-Méndez farm at Río Piedras on a Fajardo clay, a reddish-brown friable acid clay derived from old-hill alluvial material and hill-shale outwash (1). The treatments used consisted of zero, medium, and high levels of nitrogen, phosphorus, and potassium, as well as a no-fertilizer check (see table 3). Each treatment was replicated six times at a $\mathrm{pH}$ level of 5.3 (original soil $\mathrm{pH}$ ) and one of 6.5 (limed soil). Applications of 14,000 pounds of 93 -percent $\mathrm{CaCO}_{3}$ per acre were used to obtain a soil $\mathrm{pH}$ of 6.5 ; this rate was determined by the method of Riera (2). All plots were limed and fertilized at planting only.

The experimental triple-lattice design was laid out on land with a 30percent slope. There were 16 treatments and six replications. The plot size was 20 by $211 / 2$ feet or one one-hundredth of an acre. Each plot was 
separated from its neighbor by 3 -foot lanes to prevent the long vines of the kudzu from entangling.

Acid-scarified kudzu seeds were planted in paper cups in the greenhouse. After 3 weeks, the kudzu was transplanted to the field, cup and all. The spacing used in the plots was 3 feet within rows. The planting was made February 3, 1949, and the cuttings were made on July 29, 1949, November 25, 1949, and August 8, 1950. At time of cutting 500 -gm. composite samples from each plot were taken and oven-dried $\left(70^{\circ} \mathrm{C}\right.$.), to be used for the estimation of dry weights and protein analyses.

\section{Corozal Field Experiment}

In the Corozal field experiment not only various levels of lime and fertilizer, but also of minor element treatments were utilized. The experiment

TABLE 1.-Yields of kudzu in the greenhouse experiment, as influenced by soil $p H$

\begin{tabular}{c|c|c}
\hline Treatment No. & Soil pH & $\begin{array}{c}\text { Yield of kudzu in dry weight } \\
\text { per pot }\end{array}$ \\
\cline { 2 - 3 } 1 & & Grams \\
2 & 5.2 & 81.1 \\
3 & 5.5 & 88.9 \\
4 & 6.0 & 84.3 \\
5 & 6.5 & 90.1 \\
6 & 7.0 & 96.7 \\
\hline \hline
\end{tabular}

Least significant difference needed for comparison at

the:

5 -percent level

6.4

1 -percent level

8.6

was made on a Lares clay at the Corozal Substation of the Agricultural Experiment Station. The soil is an acid lateritic clay derived from washed materials of the acid red soils situated in the hills above the very old highdrained terraces where the Lares clay is found (1). The treatments used and their rates of application are given later in table 7 .

The experimental design was a triple lattice with 16 treatments and six replications laid out on land with a slope ranging from 15 to 30 percent. The plot size was one one-hundredeighty-second of an acre. The lime was applied broadcast and worked into the upper 6 inches of soil 1 month before planting. The kudzu was germinated in paper cups, containing innoculated soil from the experimental areas, and then transplanted, cups and all, when 3 weeks old. The plants were set out April 5, 1950 and cuttings were made November 6, 1950, June 19, 1951, and September 25, 
1951. Samples were taken at each cutting for estimation of dry weights (oven-dried at $70^{\circ} \mathrm{C}$.) and protein analyses.

\section{RESULTS}

\section{Greenhouse pH Experiment}

The yields of kudzu obtained in the greenhouse experiment are given in table 1 in grams per pot. The data show that, with the exception of $\mathrm{pH} 6.0$, the yields of kudzu increased with increased $\mathrm{pH}$. The highest $\mathrm{pH}$ level, 7.5, gave a 25-percent higher yield than the lowest, 5.2. The results of this experiment indicate that, at least under greenhouse conditions, tropical

TABLE 2.-Yields of tropical kudzu forage harvested at the Ceiba field experiment, as affected by various fertilizer treatments

\begin{tabular}{c|r|r|r|c}
\hline \multirow{2}{*}{ Treatment No. } & \multicolumn{3}{|c|}{ Pounds per acre of- } & $\begin{array}{c}\text { Mean yield of kudzu } \\
\text { forage, green weight } \\
\text { per acre }\end{array}$ \\
\cline { 2 - 3 } & \multicolumn{1}{|c|}{$\mathrm{N}$} & $\mathrm{P}_{2} \mathrm{O}_{5}$ & $\mathrm{~K}_{2} \mathrm{O}$ & \\
1 & & & & Tons \\
2 & 0 & 0 & 0 & 0.62 \\
3 & 0 & 200 & 200 & 1.39 \\
4 & 83 & 200 & 200 & 2.95 \\
5 & 165 & 0 & 200 & 2.66 \\
6 & 165 & 100 & 200 & 4.27 \\
7 & 165 & 200 & 0 & 4.48 \\
8 & 165 & 200 & 100 & 5.05 \\
& 165 & 200 & 200 & 3.89 \\
\hline
\end{tabular}

Mean of treatments

3.14

Least significant difference needed for comparisons at the:

1 -percent level

1.68

5 -percent level

1.26

kudzu, like alfalfa and certain clovers, responds to liming and prefers soils near a neutral $\mathrm{pH}$ (7.0) for optimum growth.

\section{Ceiba Field Experiment}

The yields of kudzu obtained in the Ceiba field experiment are presented in table 2 in green weights per acre. The use of nitrogen in combination with phosphorus and potassium gave significant yield increases. The use of 83 pounds of nitrogen per acre gave a yield increase of 1.56 tons of green kudzu forage over the no-nitrogen treatment (treatment 3 minus treatment 2 ). The use of 165 pounds of nitrogen also produced increases, but these were not significant over the first increment of 83 pounds of nitrogen (treatments 8 minus treatment 3 ). Nitrogen acting alone was responsible 
for the majority of the yield increases. If we compare treatment 2, where 200 pounds each of phosphorus and potassium were used with no nitrogen, with the unfertilized control (treatment 1), we see that the use of these two fertilizer elements alone did not give significant yield increases. When nitrogen was added, the increase in yield became significant.

The use of 100 pounds of $\mathrm{P}_{2} \mathrm{O}_{5}$ (treatment 5) gave a significant yield increase over the no-phosphorus treatment (treatment 4). The potassium treatments failed to produce a significant response. The use of nitrogen in

TABLE 3.-Yields from 3 cuttings of tropical kudzu forage (green weight), Garcia Méndez experiment, as affected by various fertilizer treatments and soil $p H$

\begin{tabular}{|c|c|c|c|c|c|c|c|c|c|c|c|c|c|}
\hline \multirow{3}{*}{$\begin{array}{l}\text { Treat- } \\
\text { ment } \\
\text { No. }\end{array}$} & \multirow{2}{*}{\multicolumn{3}{|c|}{$\begin{array}{l}\text { Pounds per } \\
\text { acre of- }\end{array}$}} & \multicolumn{10}{|c|}{ Mean yields of tropical kudzu forage harvested, green weight per acre } \\
\hline & & & & \multicolumn{2}{|c|}{ First cutting } & \multicolumn{2}{|c|}{ Second cutting } & \multicolumn{2}{|c|}{ Third cutting } & \multicolumn{2}{|c|}{$\begin{array}{c}\text { Total of } \\
3 \text { cuttings }\end{array}$} & \multicolumn{2}{|c|}{$\begin{array}{r}\text { Mean of } \\
3 \text { cuttings }\end{array}$} \\
\hline & $\mathrm{N}$ & $\mathrm{P}_{2} \mathrm{O}_{5}$ & $\mathrm{~K}_{2} \mathrm{O}$ & $\begin{array}{c}\text { Un- } \\
\text { limed } \\
\mathrm{pH} 5.3\end{array}$ & $\begin{array}{l}\text { Limed } \\
\mathrm{pH} 6.5\end{array}$ & $\begin{array}{c}\text { Un- } \\
\text { limed } \\
\text { pH 5.3 }\end{array}$ & $\begin{array}{l}\text { Limed } \\
\mathrm{pH} 6.5\end{array}$ & $\begin{array}{c}\text { Un- } \\
\text { pHed } \\
\text { pH.3 }\end{array}$ & $\begin{array}{l}\text { Limed } \\
\text { pH } 6.5\end{array}$ & $\begin{array}{c}\text { Un- } \\
\text { limed } \\
\mathrm{pH} 5.3\end{array}$ & $\begin{array}{l}\text { Limed } \\
\mathrm{pH} 6.5\end{array}$ & $\begin{array}{c}\text { Un- } \\
\text { limed } \\
\mathrm{pH} \\
5.3\end{array}$ & $\begin{array}{l}\text { Limed } \\
\text { pH } 6.5\end{array}$ \\
\hline & & & & Tons & Tons & Tons & Tons & Tons & Tons & Tons & Tons & Tons & Tons \\
\hline 1 & 0 & 0 & 0 & 3.75 & 7.39 & 5.29 & 4.58 & 7.05 & 7.41 & 16.09 & 19.38 & 5.36 & 6.46 \\
\hline 2 & 0 & 200 & 200 & 5.29 & 7.75 & 5.29 & 4.42 & 6.73 & 7.41 & 17.31 & 19.58 & 5.77 & 6.53 \\
\hline 3 & 83 & 200 & 200 & 8.43 & 9.51 & 5.13 & 5.13 & 7.60 & 8.71 & 21.16 & 23.35 & 7.05 & 7.78 \\
\hline 4 & 165 & 0 & 200 & 7.23 & 8.23 & 5.20 & 5.73 & 8.58 & 7.35 & 21.01 & 21.31 & 7.00 & 7.10 \\
\hline 5 & 165 & 100 & 200 & 7.93 & 9.08 & 5.01 & 5.28 & 8.19 & 6.66 & 21.13 & 21.02 & 7.04 & 7.01 \\
\hline 6 & 165 & 200 & 0 & 8.96 & 9.26 & 5.61 & 5.41 & 6.93 & 7.12 & 21.50 & 21.79 & 7.17 & 7.26 \\
\hline 7 & 165 & 200 & 100 & 9.60 & 9.58 & 5.14 & 4.38 & 7.79 & 8.15 & 22.53 & 22.11 & 7.51 & 7.37 \\
\hline 8 & 165 & 200 & 200 & 8.11 & 9.13 & 5.40 & 5.78 & 7.24 & 8.90 & 20.75 & 23.81 & 6.92 & 7.94 \\
\hline \multicolumn{4}{|c|}{$\begin{array}{l}\text { Mean of treat- } \\
\text { ments ....... }\end{array}$} & 7.41 & 8.74 & 5.26 & 5.09 & 7.51 & 7.71 & 20.19 & 21.54 & 6.73 & 7.18 \\
\hline
\end{tabular}

Least significant difference needed for comparison at the:
5 -percent level
2.02
1.11
1.27
2.55
0.85
1 -percent level
2.70
1.44
1.68
3.37
1.13

combination with phosphorus appears to be the required fertilizer combination for optimum yields of tropical kudzu on the Río Piedras clay in the area of the experiment. There were no further cuttings.

\section{García-Méndez Field Experiment}

\section{GREEN WEIGHT}

The yields of tropical kudzu obtained in the García-Méndez Field experiment are given in table 3 . In the first cutting the limed soils produced significantly higher yields than the unlimed in the no-fertilizer and nonitrogen treatments (treatments 1 and 2). The use of lime produced 3.64 tons more green forage than the unlimed treatment (treatment 1 ) in the 
unfertilized check. Liming with the addition of fertilizers produced no significant yield increases when no nitrogen was added (treatment 2). In the other treatments (treatments 3 to 8 ) where complete fertilizers were applied, there were no significant differences between the unlimed and limed plots.

In the first cutting, the use of 83 pounds of nitrogen gave significantly higher yields than did the no-nitrogen treatment (treatment 3 minus treatment 2) for the unlimed soils. With lime added, the use of nitrogen did not significantly raise yields. No appreciable yield increases could be attributed to the use of either phosphorus or potassium on the limed or unlimed plots.

The second and third cuttings of this experiment revealed no significant differences attributable either to liming or to fertilizers.

The total of three cuttings averaged more than 20 tons of green forage in one year for the entire experiment. With no fertilizer (treatment 1 ), the use of lime produced significant yield increases; however, these were made mostly in the first cutting. From this experiment it appears that the use of lime benefited only the first cutting, and did not produce a long-range effect. This advantage gained by liming in the first cutting disappeared with time, and the second and third cuttings showed no response to it.

Nitrogen also proved of value in starting the kudzu. Although we normally think of a legume as being an effective producer of its own nitrogen requirements, it appears that it can use a nitrogen-fertilizer boost to help establish itself on the heavy plastic Fajardo clay.

\section{DRY WEIGHT}

The yields of kudzu in dry weight of forage per acre are given in table 4 . The same trends and significance discussed under green weight appear here. The total mean yield of dry forage (oven-dried at $70^{\circ} \mathrm{C}$.) for three cuttings was over 4 tons per acre.

\section{PROTEIN}

Kudzu not only produces a good tonnage of forage for a legume crop; it also produces a high-protein forage. The protein in the kudzu on a dryweight basis ranged from 15 to 25 percent in the experiment, as can be seen in table 5 . The mean protein produced was 19.7 and 20.5 percent on a dryweight basis for the unlimed and limed treatments, respectively.

The first cutting showed increases in protein from liming, for the unfertilized plots and those receiving no nitrogen (treatments 1 and 2). When nitrogen, phosphorus, and potassium were used (treatments 3 to 8 ) no appreciable response was obtained from the use of lime. The use of 83 pounds of nitrogen per acre increased the protein in the kudzu from the unlimed plots only; when lime was used, nitrogen did not increase the protein 
TABLE 4.-Yields from 3 cuttings of tropical kudzu forage (dry weight), Garcia Méndez experiment, as affected by various fertilizer treatments and soil $\mathrm{pH}$

\begin{tabular}{|c|c|c|c|c|c|c|c|c|c|c|c|c|c|}
\hline \multirow{3}{*}{$\begin{array}{l}\text { Treat- } \\
\text { ment } \\
\text { No. }\end{array}$} & \multirow{2}{*}{\multicolumn{3}{|c|}{$\begin{array}{l}\text { Pounds per } \\
\text { acre of- }\end{array}$}} & \multicolumn{10}{|c|}{ Mean yields of tropical kudzu forage harvested, dry weight per acre } \\
\hline & & & & \multicolumn{2}{|c|}{ First cutting } & \multicolumn{2}{|c|}{ Second cutting } & \multicolumn{2}{|c|}{ Third cutting } & \multicolumn{2}{|c|}{$\begin{array}{l}\text { Total of } \\
3 \text { cuttings }\end{array}$} & \multicolumn{2}{|c|}{$\begin{array}{l}\text { Mean of } \\
3 \text { cuttings }\end{array}$} \\
\hline & $\mathrm{N}$ & $\mathrm{P}_{2} \mathrm{O}_{5}$ & $\mathrm{~K}_{2} \mathrm{O}$ & $\begin{array}{c}\text { Un- } \\
\text { limed } \\
\text { pH } 5.3\end{array}$ & $\begin{array}{l}\text { Limed } \\
\mathrm{pH} 6.5\end{array}$ & $\begin{array}{c}\text { Un- } \\
\text { limed } \\
\mathrm{pH} 5.3\end{array}$ & $\begin{array}{l}\text { Limed } \\
\mathrm{pH} 6.5\end{array}$ & $\begin{array}{c}\text { Un- } \\
\text { limed } \\
\text { pH } 5.3\end{array}$ & $\begin{array}{l}\text { Limed } \\
\mathrm{pH} 6.5\end{array}$ & $\begin{array}{c}\text { Un- } \\
\text { limed } \\
\text { pH } 5.3\end{array}$ & $\begin{array}{l}\text { Limed } \\
\mathrm{pH} 6.5\end{array}$ & $\begin{array}{l}\text { Un- } \\
\text { limed } \\
\mathrm{pH} 5.3\end{array}$ & $\begin{array}{l}\text { Limed } \\
\mathrm{pH} 6.5\end{array}$ \\
\hline & & & & Tons & Tons & Tons & Tons & Tons & Tons & Tons & Tons & Tons & Tons \\
\hline 1 & 0 & 0 & 0 & 0.75 & 1.32 & 0.92 & 0.84 & 1.84 & 1.88 & 3.51 & 4.04 & 1.17 & 1.35 \\
\hline 2 & 0 & 200 & 200 & 1.01 & 1.32 & .94 & .72 & 1.95 & 1.94 & 3.90 & 3.98 & 1.30 & 1.33 \\
\hline 3 & 83 & 200 & 200 & 1.50 & 1.62 & .86 & .84 & 1.84 & 2.09 & 4.20 & 4.55 & 1.40 & 1.52 \\
\hline 4 & 165 & 0 & 200 & 1.30 & 1.41 & .89 & .95 & 1.79 & 2.07 & 3.98 & 4.43 & 1.33 & 1.48 \\
\hline 5 & 165 & 100 & 200 & 1.28 & 1.62 & .88 & .88 & 1.90 & 2.12 & 4.06 & 4.62 & 1.35 & 1.54 \\
\hline 6 & 165 & 200 & 0 & 1.50 & 1.64 & 1.04 & .94 & 1.84 & 1.86 & 4.38 & 4.44 & 1.46 & 1.48 \\
\hline 7 & 165 & 200 & 100 & 1.59 & 1.65 & .83 & .72 & 1.85 & 1.93 & 4.27 & 4.30 & 1.42 & 1.43 \\
\hline 8 & 165 & 200 & 200 & 1.49 & 1.69 & .97 & 1.07 & 1.95 & 2.15 & 4.41 & 4.91 & 1.47 & 1.44 \\
\hline \multicolumn{4}{|c|}{$\begin{array}{l}\text { Mean of treat- } \\
\text { ments } . . . . .\end{array}$} & 1.30 & 1.53 & 0.92 & 0.87 & 1.87 & 2.01 & 4.09 & 4.41 & 1.36 & 1.45 \\
\hline \multirow{2}{*}{\multicolumn{4}{|c|}{$\begin{array}{l}5 \text {-percent level } \\
1 \text {-percent level }\end{array}$}} & \multicolumn{2}{|r|}{0.36} & \multicolumn{2}{|c|}{0.20} & \multicolumn{2}{|c|}{0.31} & \multicolumn{2}{|c|}{0.47} & \multicolumn{2}{|l|}{0.16} \\
\hline & & & & & .48 & \multicolumn{2}{|c|}{.26} & & & \multicolumn{2}{|c|}{.62} & .21 & \\
\hline
\end{tabular}

TABLE 5.-Protein in 3 cuttings of tropical kudzu forage, Garcia Méndez experiment, as affected by various fertilizer treatments and soil $\mathrm{pH}$

\begin{tabular}{|c|c|c|c|c|c|c|c|c|c|c|c|}
\hline \multirow{3}{*}{$\begin{array}{c}\text { Treatment } \\
\text { No. }\end{array}$} & \multirow{2}{*}{\multicolumn{3}{|c|}{$\begin{array}{l}\text { Pounds per } \\
\text { acre of }-\end{array}$}} & \multicolumn{8}{|c|}{ Mean protein content of tropical kudzu harvested, dry weight } \\
\hline & & & & \multicolumn{2}{|c|}{ First cutting } & \multicolumn{2}{|c|}{ Second cutting } & \multicolumn{2}{|c|}{ Third cutting } & \multicolumn{2}{|c|}{$\begin{array}{l}\text { Mean of } \\
3 \text { cuttings }\end{array}$} \\
\hline & $\mathrm{N}$ & $\mathrm{P}_{2} \mathrm{O}_{5}$ & $\mathrm{~K}_{2} \mathrm{O}$ & $\begin{array}{c}\text { Un- } \\
\text { limed } \\
\text { pH 5.3 }\end{array}$ & $\begin{array}{l}\text { Limed } \\
\mathrm{pH} 6.5\end{array}$ & $\begin{array}{c}\text { Un- } \\
\text { limed } \\
\text { pH } 5.3\end{array}$ & $\begin{array}{l}\text { Limed } \\
\text { pH 6.5 }\end{array}$ & $\begin{array}{c}\text { Un. } \\
\text { limed } \\
\mathrm{pH} 5.3\end{array}$ & $\begin{array}{l}\text { Limed } \\
\text { pH } 6.5\end{array}$ & $\begin{array}{c}\text { Un- } \\
\text { limed } \\
\mathrm{pH} 5.3\end{array}$ & $\begin{array}{l}\text { Limed } \\
\text { pH } 6.5\end{array}$ \\
\hline & & & & Percent & Percent & Percent & Percent & Percent & Percent & Percent & Percent \\
\hline 1 & 0 & 0 & 0 & 15.3 & 17.8 & 16.2 & 17.7 & 22.8 & 23.7 & 18.1 & 19.7 \\
\hline 2 & 0 & 200 & 200 & 16.8 & 19.2 & 17.4 & 17.8 & 22.1 & 25.0 & 18.8 & 20.7 \\
\hline 3 & 83 & 200 & 200 & 18.6 & 18.9 & 18.7 & 17.8 & 22.9 & 23.4 & 20.1 & 20.0 \\
\hline 4 & 165 & 0 & 200 & 18.4 & 19.4 & 18.2 & 19.1 & 21.1 & 22.1 & 19.2 & 20.2 \\
\hline 5 & 165 & 100 & 200 & 18.7 & 18.8 & 18.8 & 19.0 & 22.5 & 24.0 & 20.0 & 20.0 \\
\hline 6 & 165 & 200 & 0 & 18.7 & 18.5 & 18.3 & 18.7 & 24.1 & 24.5 & 20.4 & 20.6 \\
\hline 7 & 165 & 200 & 100 & 18.6 & 20.1 & 19.5 & 20.3 & 23.7 & 23.9 & 20.6 & 21.4 \\
\hline 8 & 165 & 200 & 200 & 18.8 & 20.2 & 18.5 & 18.4 & 23.6 & 22.6 & 20.3 & 20.4 \\
\hline \multicolumn{4}{|l|}{ Means } & 18.0 & 19.1 & 18.2 & 18.6 & 22.9 & 23.7 & 19.7 & 20.5 \\
\hline
\end{tabular}

Least significant difference needed for comparison at the:
5 -percent level
1.8
1.7
1.9
1-percent level
2.4
2.3
2.6 
content (treatment 3 minus treatment 2). As found for yields of forage (tables 3 and 4 ) the use of nitrogen on kudzu was more effective on the unlimed than on the limed soils. The application of phosphorus or potassium fertilizers had no measurable influence on protein yields.

The second cutting showed no appreciable differences in protein content when lime was used; nor did nitrogen, phosphorus, or potassium fertilizers increase protein yields.

TaBle 6.-Yields of protein harvested in 3 cuttings of tropical kudzu, Garcia Méndez experiment, as affected by various fertilizer treatments and soil $p H$

\begin{tabular}{|c|c|c|c|c|c|c|c|c|c|c|c|c|c|}
\hline \multirow{3}{*}{ 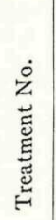 } & \multirow{2}{*}{\multicolumn{3}{|c|}{$\begin{array}{l}\text { Pounds per } \\
\text { acre of }-\end{array}$}} & \multicolumn{10}{|c|}{ Mean yields of protein harvested from tropical kudzu, dry weight per acre } \\
\hline & & & & \multicolumn{2}{|c|}{ First cutting } & \multicolumn{2}{|c|}{ Second cutting } & \multicolumn{2}{|c|}{ Third cutting } & \multicolumn{2}{|c|}{$\begin{array}{c}\text { Total of } \\
3 \text { cuttings }\end{array}$} & \multicolumn{2}{|c|}{$\begin{array}{l}\text { Mean of } \\
3 \text { cuttings }\end{array}$} \\
\hline & $\mathrm{N}$ & $\mathrm{P}_{2} \mathrm{O}_{5}$ & $\mathrm{~K}_{2} \mathrm{O}_{5}$ & $\mid$\begin{tabular}{c|} 
Un- \\
limed \\
$\mathrm{pH} 5.3$
\end{tabular} & $\left|\begin{array}{l}\text { Limed } \\
\mathrm{pH}\end{array} 6.5\right|$ & $\begin{array}{c}\text { Un- } \\
\text { limed } \\
\mathrm{pH} 5.3\end{array}$ & $\begin{array}{l}\text { Limed } \\
\mathrm{pH} 6.5\end{array}$ & $\begin{array}{l}\text { Un- } \\
\text { limed } \\
\mathrm{pH} 5.3\end{array}$ & $\begin{array}{l}\text { Limed } \\
\text { pH } 6.5\end{array}$ & $\begin{array}{c}\text { Un- } \\
\text { limed } \\
\mathrm{pH} 5.3\end{array}$ & $\begin{array}{l}\text { Limed } \\
\text { pH } 6.5\end{array}$ & $\begin{array}{l}\text { Un- } \\
\text { limed } \\
\text { pH } 5.3\end{array}$ & $\begin{array}{l}\text { Limed } \\
\text { pH } 6.5\end{array}$ \\
\hline & & & & Pounds & Pounds & Pounds & Pounds & Pounds & Pounds & Pounds & Pounds & Pounds & Pounds \\
\hline 1 & 0 & 0 & 0 & 229 & 470 & 298 & 297 & 839 & 891 & 1,366 & 1,658 & 455 & 553 \\
\hline 2 & 0 & 200 & 200 & 339 & 507 & 327 & 256 & 862 & 970 & 1,528 & 1,733 & 509 & 577 \\
\hline 3 & 83 & 200 & 200 & 558 & 612 & 322 & 299 & 843 & 978 & 1,723 & 1,889 & 574 & 630 \\
\hline 4 & 165 & 0 & 200 & 478 & 547 & 324 & 363 & 755 & 915 & 1,557 & 1,825 & 519 & 608 \\
\hline 5 & 165 & 100 & 200 & 479 & 609 & 331 & 334 & 855 & 1018 & 1,665 & 1,961 & 555 & 654 \\
\hline 6 & 165 & 200 & 0 & 561 & 607 & 380 & 352 & 887 & 911 & 1,828 & 1,870 & 609 & 623 \\
\hline 7 & 165 & 200 & 100 & 591 & 663 & 324 & 292 & 877 & 922 & 1,792 & 1,877 & 597 & 626 \\
\hline 8 & 165 & 200 & 200 & 560 & 683 & 359 & 394 & 920 & 972 & 1,839 & 2,049 & 613 & 683 \\
\hline \multicolumn{4}{|c|}{$\begin{array}{l}\text { Means of } \\
\text { treatments. }\end{array}$} & 474 & 587 & 333 & 323 & 855 & 947 & 1,662 & 1,858 & 554 & 619 \\
\hline
\end{tabular}

Least significant difference needed for comparison at the:

1 -percent

$\begin{array}{cccccc}\begin{array}{c}\text { level } \\ \text {-percent } \\ \text { level }\end{array} & 176 & 107 & 203 & 262 & 87 \\ & 133 & 81 & 153 & 198 & 66\end{array}$

In the third cutting there was an increase in protein content when lime was applied in the no-nitrogen treatment (treatment 2). However, this was the only significant response to liming. The use of nitrogen, phosphorus, or potassium fertilizers did not appreciably increase the protein content of the kudzu.

Most of the protein concentrate for animal feeds is imported into Puerto Rico. It is therefore of interest to see how large a yield of protein in pounds per acre (dry-weight basis) was produced. The results obtained are given in table 6 . The total of three cuttings produced a mean yield of over 1,700 pounds of protein per acre. It would require 8.5 tons, or 305 bushels $^{4}$, of

${ }^{4}$ One bushel of shelled corn equal to 56 pounds. 
corn to produce the same quantity. There is no doubt about the saving in money and shipping space tropical kudzu grown locally can mean to the people of Puerto Rico.

TABLE 7.-Yields from 3 cuttings of tropical lidzu forage (green weight), Corozal experiment, as affected by various fertilizer treatments, including minor elements, and soil $p H$

\begin{tabular}{|c|c|c|c|c|c|c|c|c|c|c|}
\hline \multirow{2}{*}{$\begin{array}{l}\text { Treatment } \\
\text { No. }\end{array}$} & \multicolumn{3}{|c|}{$\begin{array}{l}\text { Pounds per } \\
\text { acre of }-\end{array}$} & \multirow{2}{*}{$\begin{array}{l}\text { Lime } \\
\text { used per } \\
\text { acre }\end{array}$} & \multirow{2}{*}{$\begin{array}{l}\text { Soil } \\
\mathrm{pH}\end{array}$} & \multicolumn{5}{|c|}{$\begin{array}{l}\text { Mean yields of tropical kudzu forage, green weight } \\
\text { per acre }\end{array}$} \\
\hline & $\mathrm{N}$ & $\mathrm{P}_{2} \mathrm{O}_{5}$ & $\mathrm{~K}_{2} \mathrm{O}$ & & & $\begin{array}{c}\text { First } \\
\text { cutting }\end{array}$ & $\begin{array}{l}\text { Second } \\
\text { cutting }\end{array}$ & $\begin{array}{c}\text { Third } \\
\text { cutting }\end{array}$ & $\begin{array}{l}\text { Total } \\
\text { of } 3 \\
\text { cuttings }\end{array}$ & $\begin{array}{l}\text { Mean } \\
\text { of } 3 \\
\text { cuttings }\end{array}$ \\
\hline & & & & Pounds & & Tons & Tons & Tons & Tons & Tons \\
\hline 1 & 0 & 0 & 0 & 7,500 & 6.0 & 6.95 & 3.91 & 4.46 & 15.32 & 5.11 \\
\hline 2 & 0 & 200 & 200 & 7,500 & 6.0 & 5.44 & 4.91 & 3.82 & 14.18 & 4.73 \\
\hline 3 & 83 & 200 & 200 & 7,500 & 6.0 & 6.57 & 5.10 & 4.57 & 16.23 & 5.41 \\
\hline 4 & 165 & 0 & 200 & 7,500 & 6.0 & 6.68 & 4.55 & 3.44 & 14.67 & 4.90 \\
\hline 5 & 165 & 100 & 200 & 7,500 & 6.0 & 6.10 & 4.28 & 3.53 & 13.90 & 4.64 \\
\hline 6 & 165 & 200 & 0 & 7,500 & 6.0 & 6.33 & 4.28 & 3.68 & 14.29 & 4.77 \\
\hline 7 & 165 & 200 & 100 & 7,500 & 6.0 & 6.00 & 4.46 & 3.79 & 14.31 & 4.77 \\
\hline 8 & 165 & 200 & 200 & 7,500 & 6.0 & 5.97 & 3.91 & 3.80 & 13.69 & 4.57 \\
\hline 9 & 0 & 0 & 0 & 0 & 4.5 & 6.59 & 3.46 & 3.55 & 13.60 & 4.53 \\
\hline 10 & 83 & 200 & 200 & 3,500 & 5.0 & 6.10 & 4.19 & 4.00 & 14.29 & 4.77 \\
\hline 11 & 83 & 200 & 200 & 12,500 & 7.0 & 5.97 & 5.10 & 4.46 & 15.52 & 5.17 \\
\hline $12^{1}$ & 83 & 200 & 200 & 0 & 4.5 & 5.95 & 2.55 & 3.75 & 12.25 & 4.08 \\
\hline $13^{1}$ & 83 & 200 & 200 & 7,500 & 6.0 & .5 .70 & 4.10 & 3.62 & 13.41 & 4.48 \\
\hline $14^{1}$ & 83 & 200 & 200 & 12,500 & 7.0 & 6.64 & 5.10 & 4.53 & 16.27 & 5.42 \\
\hline $15^{2}$ & 83 & 200 & 200 & 0 & 4.5 & 5.73 & 4.28 & 3.89 & 13.90 & 4.64 \\
\hline $16^{2}$ & 83 & 200 & 200 & 7,500 & 6.0 & 6.52 & 4.10 & 4.50 & 15.11 & 5.04 \\
\hline \multicolumn{6}{|c|}{ Mean of all treatments. } & 6.21 & 4.26 & 3.97 & 14.43 & 4.82 \\
\hline \multicolumn{11}{|c|}{$\begin{array}{l}\text { Least significant difference needed for } \\
\text { comparisons at the: }\end{array}$} \\
\hline \multicolumn{6}{|c|}{ 1-percent level. . . . . . } & 1.64 & 1.71 & 1.26 & 2.73 & .91 \\
\hline \multicolumn{6}{|c|}{5 -percent level. } & 1.24 & 1.29 & .95 & 2.02 & .67 \\
\hline
\end{tabular}

1 Plus 50 pounds of borax.

${ }^{2}$ Plus 300 pounds of magnesium oxide.

\section{Corozal Field Experiment}

\section{GREEN WEIGHT}

The yields of forage obtained in the Corozal field experiment are given in table 7 in green weight. In the first cutting applications of lime up to 12,500 pounds per acre failed to produce significant yield increases (treatments 1, 3, 10, and 11) as compared with yields from unlimed soil (treatment 9). The use of nitrogen, phosphorus, or potassium fertilizer did not give any significant increases in yields. Minor-element fertilizers, magne- 
sium oxide and borax, used at various $\mathrm{pH}$ levels did not measurably increase yields (treatments 12 to 16 ).

The first cutting of this experiment did not respond to liming and nitrogen as did that in the García-Méndez experiment. The normal soil $\mathrm{pH}$ encountered here was about 4.5, which was lower than the 5.3 of the Fa-

TABLE 8.-Yields from 3 cuttings of tropical kudzu forage (dry weight) Corozal experiment, as affected by various fertilizer treatments, including minor elements, and by soil $\mathrm{pH}$

\begin{tabular}{|c|c|c|c|c|c|c|c|c|c|c|}
\hline \multirow{2}{*}{$\begin{array}{c}\text { Treat- } \\
\text { ment } \\
\text { No. }\end{array}$} & \multicolumn{3}{|c|}{$\begin{array}{l}\text { Pounds per } \\
\text { acre of }-\end{array}$} & \multirow{2}{*}{$\begin{array}{l}\text { Lime } \\
\text { used per } \\
\text { acre }\end{array}$} & \multirow{2}{*}{$\begin{array}{l}\text { Soil } \\
\mathrm{pH}\end{array}$} & \multicolumn{5}{|c|}{$\begin{array}{l}\text { Mean yield of tropical kudzu forage dry weight } \\
\text { per acre }\end{array}$} \\
\hline & $\mathrm{N}$ & $\mathrm{P}_{2} \mathrm{O}_{5}$ & $\mathrm{~K}_{2} \mathrm{O}$ & & & $\begin{array}{c}\text { First } \\
\text { cutting }\end{array}$ & $\begin{array}{l}\text { Second } \\
\text { cutting }\end{array}$ & $\begin{array}{l}\text { Third } \\
\text { cutting }\end{array}$ & $\begin{array}{c}\text { Total of } 3 \\
\text { cuttings }\end{array}$ & $\begin{array}{l}\text { Mean of } 3 \\
\text { cuttings }\end{array}$ \\
\hline & & & & Pounds & & Tons & Tons & Tons & Tons & Tons \\
\hline 1 & 0 & 0 & 0 & 7,500 & 6.0 & 1.80 & 1.13 & 0.84 & 3.77 & 1.26 \\
\hline 2 & 0 & 200 & 200 & 7,500 & 6.0 & 1.36 & 1.33 & .75 & 3.44 & 1.15 \\
\hline 3 & 83 & 200 & 200 & 7,500 & 6.0 & 1.64 & 1.49 & .86 & 3.99 & 2.48 \\
\hline 4 & 165 & 0 & 200 & 7,500 & 6.0 & 1.75 & 1.40 & .71 & 3.86 & 1.29 \\
\hline 5 & 165 & 100 & 200 & 7,500 & 6.0 & 1.58 & 1.31 & .84 & 3.73 & 1.24 \\
\hline 6 & 165 & 200 & 0 & 7,500 & 6.0 & 1.73 & 1.27 & .73 & 3.73 & 1.24 \\
\hline 7 & 165 & 200 & 100 & 7,500 & 6.0 & 1.47 & 1.29 & .76 & 3.53 & 1.18 \\
\hline 8 & 165 & 200 & 200 & 7,500 & 6.0 & 1.58 & 1.16 & .66 & 3.40 & 1.13 \\
\hline 9 & 0 & 0 & 0 & 0 & 4.5 & 1.69 & .98 & .71 & 3.39 & 1.13 \\
\hline 10 & 83 & 200 & 200 & 3,500 & 5.0 & 1.55 & 1.26 & .62 & 3.42 & 1.15 \\
\hline 11 & 83 & 200 & 200 & 12,500 & 7.0 & 1.58 & 1.49 & .86 & 3.93 & 1.31 \\
\hline $12^{1}$ & 83 & 200 & 200 & 0 & 4.5 & 1.44 & .82 & .75 & 3.00 & 1.00 \\
\hline $13^{1}$ & 83 & 200 & 200 & 7,500 & 6.0 & 1.58 & 1.27 & .64 & 3.49 & 1.16 \\
\hline $14^{1}$ & 83 & 200 & 200 & 12,500 & 7.0 & 1.49 & 1.49 & .82 & 3.80 & 1.27 \\
\hline $15^{2}$ & 83 & 200 & 200 & 0 & 4.5 & 1.77 & 1.16 & .76 & 3.69 & 1.24 \\
\hline $16^{2}$ & 83 & 200 & 200 & 7,500 & 6.0 & 1.36 & 1.11 & .84 & 3.31 & 1.11 \\
\hline \multicolumn{6}{|c|}{ Mean of treatments............. } & 1.58 & 1.26 & .76 & 3.59 & 1.20 \\
\hline \multirow{3}{*}{\multicolumn{6}{|c|}{$\begin{array}{l}\text { Least significant differences needed for } \\
\text { comparison at the: }\end{array}$}} & & & & & \\
\hline & & & & & & 0.36 & 0.42 & 0.20 & & \\
\hline & & & & & & .49 & .55 & .27 & & \\
\hline
\end{tabular}

${ }^{1}$ Plus 50 pounds of borax.

2 Plus 300 pounds of magnesium oxide.

jardo clay at García-Méndez. Soil samples taken after the first cutting revealed that the unlimed plots had a mean $\mathrm{pH}$ of 5.4, and there was evidence of washing of lime from limed to unlimed plots. It was probable that the heavy rains at the beginning of the experiment, before sufficient ground cover was established by the kudzu, washed some of the lime from the limed to the unlimed plots. 
The second and third cuttings gave no indications of yield increases that could be attributed to any of the treatments used.

It appears that in the more friable and better drained soils of the Lares clay, as compared with the plastic, poorly drained Fajardo clay, the kudzu

TABLE 9.-Protein in 3 cuttings of tropical kudzu forage, Corozal experiment, as affected by various fertilizer treatments, including minor elements, and by soil $p H$

\begin{tabular}{|c|c|c|c|c|c|c|c|c|c|}
\hline \multirow{2}{*}{$\begin{array}{l}\text { Treatment } \\
\text { No. }\end{array}$} & \multicolumn{3}{|c|}{$\begin{array}{l}\text { Pounds per } \\
\text { acre of }-\end{array}$} & \multirow{2}{*}{$\begin{array}{l}\text { Lime } \\
\text { used per } \\
\text { acre }\end{array}$} & \multirow{2}{*}{$\begin{array}{l}\text { Soil } \\
\text { pH }\end{array}$} & \multicolumn{4}{|c|}{$\begin{array}{l}\text { Mean protein content of tropical kudzu, } \\
\text { dry weight }\end{array}$} \\
\hline & $N$ & $\mathrm{P}_{2} \mathrm{O}_{5}$ & $\mathrm{~K}_{2} \mathrm{O}$ & & & $\begin{array}{c}\text { First } \\
\text { cutting }\end{array}$ & $\begin{array}{l}\text { Second } \\
\text { cutting }\end{array}$ & $\begin{array}{l}\text { Third } \\
\text { cutting }\end{array}$ & $\begin{array}{c}\text { Mean of } 3 \\
\text { cuttings }\end{array}$ \\
\hline & & & & Pounds & & Percent & Percent & Percent & Percent \\
\hline 1 & 0 & 0 & 0 & 7,500 & 6.0 & 18.9 & 17.1 & 18.6 & 18.2 \\
\hline 2 & 0 & 200 & 200 & 7,500 & 6.0 & 18.2 & 15.0 & 17.9 & 17.0 \\
\hline 3 & 83 & 200 & 200 & 7,500 & 6.0 & 19.8 & 16.4 & 18.0 & 18.1 \\
\hline 4 & 165 & 0 & 200 & 7,500 & 6.0 & 19.0 & 16.9 & 18.0 & 18.0 \\
\hline 5 & 165 & 100 & 200 & 7,500 & 6.0 & 19.3 & 14.6 & 18.2 & 17.4 \\
\hline 6 & 165 & 200 & 0 & 7,500 & 6.0 & 21.2 & 16.8 & 19.3 & 19.1 \\
\hline 7 & 165 & 200 & 100 & 7,500 & 6.0 & 20.2 & 16.8 & 18.1 & 18.4 \\
\hline 8 & 165 & 200 & 200 & 7,500 & 6.0 & 19.0 & 18.4 & 19.4 & 18.9 \\
\hline 9 & 0 & 0 & 0 & 0 & 4.5 & 18.0 & 12.6 & 16.2 & 15.6 \\
\hline 10 & 83 & 200 & 200 & 3,500 & 5.0 & 20.0 & 16.4 & 17.8 & 18.1 \\
\hline 11 & 83 & 200 & 200 & 12,500 & 7.0 & 19.6 & 18.0 & 18.0 & 18.5 \\
\hline $12^{1}$ & 83 & 200 & 200 & 0 & 4.5 & 18.1 & 13.9 & 15.7 & 15.9 \\
\hline $13^{1}$ & 83 & 200 & 200 & 7,500 & 6.0 & 20.8 & 17.3 & 17.6 & 18.6 \\
\hline $14^{1}$ & 83 & 200 & 200 & 12,500 & 7.0 & 19.9 & 15.7 & 17.5 & 17.7 \\
\hline $15^{2}$ & 83 & 200 & 200 & 0 & 4.5 & 18.9 & 14.8 & 17.4 & 17.0 \\
\hline $16^{2}$ & 83 & 200 & 200 & 7,500 & 6.0 & 19.03 & 16.0 & 17.3 & 17.4 \\
\hline \multicolumn{6}{|c|}{ 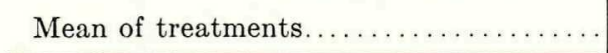 } & 19.37 & 16.04 & 17.81 & 17.74 \\
\hline \multirow{3}{*}{\multicolumn{6}{|c|}{$\begin{array}{l}\text { Least significant difference needed for com- } \\
\text { parison at the: } \\
\text { 5-percent level } \\
\text { 1-percent level }\end{array}$}} & & & & \\
\hline & & & & & & 2.5 & 2.2 & 1.80 & 1.34 \\
\hline & & & & & & 3.3 & 2.9 & 2.39 & 1.78 \\
\hline
\end{tabular}

${ }^{1}$ Plus 50 pounds of borax.

${ }^{2}$ Plus 300 pounds of magnesium oxide.

was able to establish itself fast enough to make the use of lime or fertilizers of negligible value.

\section{DRY WEIGHT}

The yields of kudzu forage on a dry-weight basis are given in table 8 . The trends are similar to those discussed under green weight. In general, there was no appreciable response for the three cuttings to either lime, major-element, or minor-element fertilizers. 


\section{PROTEIN}

The protein content of the kudzu harvested at Corozal is given in table 9. In the first cutting lime used alone failed to produce significant increases in protein content. The combination of lime and complete fertilizer with or without minor elements also failed to give consistent significant increases in protein content of the kudzu.

TABLE 10.-Yields of protein harvested in 3 cuttings of tropical kudzu, Corozal experiment, as affected by various fertilizer treatments, including minor elements, and by soil $\mathrm{pH}$

\begin{tabular}{|c|c|c|c|c|c|c|c|c|c|c|}
\hline \multirow{2}{*}{$\begin{array}{l}\text { Treatment } \\
\text { No. }\end{array}$} & \multicolumn{3}{|c|}{$\begin{array}{l}\text { Pounds per } \\
\text { acre of }-\end{array}$} & \multirow{2}{*}{$\begin{array}{l}\text { Lime } \\
\text { used per } \\
\text { acre }\end{array}$} & \multirow{2}{*}{$\begin{array}{l}\text { Soil } \\
\mathrm{pH}\end{array}$} & \multicolumn{5}{|c|}{$\begin{array}{l}\text { Mean yield of protein harvested from tropical } \\
\text { kudzu, dry weight per acre }\end{array}$} \\
\hline & $\mathrm{N}$ & $\mathrm{P}_{2} \mathrm{O}_{5}$ & $\mathrm{~K}_{2} \mathrm{O}$ & & & $\begin{array}{c}\text { First } \\
\text { cutting }\end{array}$ & $\begin{array}{l}\text { Second } \\
\text { cutting }\end{array}$ & $\begin{array}{c}\text { Third } \\
\text { cutting }\end{array}$ & $\begin{array}{c}\text { Total } \\
\text { of } 3 \\
\text { cuttings }\end{array}$ & $\begin{array}{c}\text { Mean } \\
\text { of } 3 \\
\text { cuttings }\end{array}$ \\
\hline & & & & Pounds & & Pounds & Pounds & Pounds & Pounds & Pounds \\
\hline 1 & 0 & 0 & 0 & 7,500 & 6.0 & 680 & 390 & 310 & 1,380 & 460 \\
\hline 2 & 0 & 200 & 200 & 7,500 & 6.0 & 500 & 400 & 270 & 1,170 & 390 \\
\hline 3 & 83 & 200 & 200 & 7,500 & 6.0 & 650 & 490 & 310 & 1,450 & 483 \\
\hline 4 & 165 & 0 & 200 & 7,500 & 6.0 & 660 & 470 & 260 & 1,390 & 463 \\
\hline 5 & 165 & 100 & 200 & 7,500 & 6.0 & 610 & 380 & 310 & 1,300 & 433 \\
\hline 6 & 165 & 200 & 0 & 7,500 & 6.0 & 730 & 430 & 280 & 1,440 & 480 \\
\hline 7 & 165 & 200 & 100 & 7,500 & 6.0 & 590 & 430 & 280 & 1,300 & 433 \\
\hline 8 & 165 & 200 & 200 & 7,500 & 6.0 & 600 & 430 & 260 & 1,290 & 430 \\
\hline 9 & 0 & 0 & 0 & 0 & 4.5 & 610 & 250 & 230 & 1,090 & 363 \\
\hline 10 & 83 & 200 & 200 & 3,500 & 5.0 & 620 & 410 & 220 & 1,250 & 417 \\
\hline 11 & 83 & 200 & 200 & 12,500 & 7.0 & 620 & 540 & 310 & 1,470 & 490 \\
\hline $12^{1}$ & 83 & 200 & 200 & 0 & 4.5 & 520 & 230 & 240 & 990 & 330 \\
\hline $13^{1}$ & 83 & 200 & 200 & 7,500 & 6.0 & 660 & 440 & 230 & 1,330 & 443 \\
\hline $14^{1}$ & 83 & 200 & 200 & 12,500 & 7.0 & 590 & 470 & 290 & 1,350 & 450 \\
\hline $15^{2}$ & 83 & 200 & 200 & 0 & 4.5 & 670 & 340 & 260 & 1,270 & 423 \\
\hline $16^{2}$ & 83 & 200 & 200 & 7,500 & 6.0 & 520 & 360 & 290 & 1,170 & 390 \\
\hline \multicolumn{6}{|c|}{ Mean of treatments................... } & 614 & 404 & 272 & 1,290 & 430 \\
\hline
\end{tabular}

${ }^{1}$ Plus 50 pounds of borax.

${ }^{2}$ Plus 300 pounds of magnesium oxide.

The use of lime produced significant increases in protein for the second and third cuttings when no fertilizer was used (compare treatments 1 and 9 ). The use of nitrogen, phosphorus, or potassium fertilizers failed to show consistent increases in the protein content. The application of borax in combination with fertilizer and lime did not produce consistent increases in the protein content of the kudzu. The same was true for magnesium oxide (treatments 15 and 16).

The mean of the three cuttings revealed that lime when used alone gave 
significant increases in the protein content of the kudzu, but these increases were encountered in the second and third cuttings only. This result is just the reverse of the findings in the García-Méndez experiment where liming was effective in the first cutting only. At Corozal it appears that lime had its normal long-range effect and it produced beneficial results in the later cuttings. At present no explanation can be offered of this reversal in the behavior of the lime on kudzu.

The pounds of protein produced per acre are given in table 10 . The results are similar to those discussed for the percentage of protein in table 9 . The mean yields indicate that the total weight of protein produced was somewhat higher for the García-Méndez experiment. The Corozal experiment gave larger yields in the first cutting which decreased with the number of cuttings. At García-Méndez, the third cuttings gave higher yields than did the other two.

\section{DISCUSSION}

The usual recommendation for growing legumes is to use soils near neutral $(\mathrm{pH} 7)$ and to lime acid soils. No nitrogen is usually recommended, as the legume is assumed to be an efficient producer of its own nitrogen. It appears from the results of these field experiments, that nitrogen can be of value in establishing a stand of kudzu. The nitrogen fertilizer increases both yield and protein content of the plant. The beneficial effect of nitrogen applications is quickly realized in the cutting to which it is applied, but the gains are not so evident in subsequent cuttings. Observations made by the authors on field plots have shown a marked reduction in nodulation when nitrogen fertilizers had been recently applied to the soil for new plantings. Six months after the application of the nitrogen, the plots showed an increase in nodulation.

Tropical kudzu has displayed an ability to grow well at $\mathrm{pH}$ 's in the range of 4.5 to 5.5. However, the use of lime stimulated yields in both greenhouse and field experiments. In the García-Méndez experiment, the yield increase from liming was realized on the heavy, plastic Fajardo clay in the first cutting only, whereas, in the Corozal experiment, there was a significant increase in protein from liming in only the second and third cuttings, and no increase at all in yields of forage that could be attributed to liming.

In all the experiments, except for the one in Ceiba, the use of phosphorus fertilizers produced neither yield nor protein increases. Potassium fertilizers had no significant influence on the yields of kudzu in the experiments discussed. However, evidences of potassium deficiencies have been noted by the authors on kudzu growing in sandy soils such as the Cataño loamy sand. 


\section{SUMMARY}

The effect of fertilizers and lime on the yield and protein production of tropical kudzu, as observed in the experiments here reported, is as follows:

1. In a greenhouse experiment, kudzu yields increased with increased $\mathrm{pH}$ on limed soils, with the highest yield at $\mathrm{pH} 7.5$.

2. Nitrogen and phosphorus produced significant increases in the yield of green forage in a fertilizer experiment on a Río Piedras clay. No such increases were obtained with potash fertilizers.

3. Liming increased yields for the first cutting of kudzu only in a fertilizer-lime experiment on a heavy plastic Fajardo clay. Nitrogen was also of significant value in increasing forage yields and protein for the first cutting only. The second and third cuttings had no yield or protein increases that could be attributed to any fertilizer or lime treatment.

4. At Corozal, on a friable, acid Lares clay, kudzu did not respond to nitrogen, phosphorus, and potassium fertilizers. The response to liming was in protein content and then only in the second and third cuttings.

5 . The use of nitrogen and lime is of value in establishing good productive stands of kudzu on very acid soils ( $\mathrm{pH}$ below 5 ) of low fertility.

6 . The effects of the use of borax and of magnesium oxide as minorelement fertilizers were negligible from the standpoint of yield and protein production.

\section{RESUMEN}

A continuación, se informan los efectos de los abonos y la cal sobre el rendimiento y contenido de proteína del Kudzu tropical, según se observaron en los experimentos que se detallan en el presente trabajo.

1. En un experimento, llevado a cabo en invernadero (green-house), los rendimientos del kudzu aumentaron, según se subió el $\mathrm{pH}$ en los terrenos encalados, resultando el mayor rendimiento en los terrenos con un $\mathrm{pH}$ de 7.5 .

2. El nitrógeno y el fósforo produjeron resultados significativos en el rendimiento del forraje verde del kudzu, en un experimento con abonos en suelo Río Piedras arcilloso. Sin embargo, no se observó aumento alguno en los rendimientos en el mismo suelo, cuando se aplicaron abonos potásicos.

3. Las aplicaciones de cal aumentaron los rendimientos del primer corte de Kudzu sólo en un experimento combinado de aplicaciones de abonos y cal llevado a cabo en un suelo Fajardo pesado, plástico y arcilloso. El nitrógeno también fué de valor significativo para aumentar el rendimiento del forraje y su contenido de proteína, en cuanto al primer corte únicamente. Los cortes segundo y tercero no tuvieron aumentos en el rendi- 
miento del forraje, ni en su contenido de proteína, que pudieran atribuirse a la aplicación de abono alguno o de la cal.

4. En Corozal, en un suelto y ácido arcilla Lares, el Kudzu no respondió a las aplicaciones de nitrógeno, fósforo y potasa. Reaccionó favorablemente, en cuanto al contenido de proteína, cuando se le aplicó cal al mismo suelo, pero sólo en los cortes segundo y tercero.

5. La aplicación de nitrógeno y cal a los terrenos muy ácidos y pobres, con un $\mathrm{pH}$ de menos de 5, ayuda a establecer buenas siembras de Kudzu.

6. Los compuestos de boro y el óxido de magnesio, usados como elementos menores en el abonamiento del Kudzu, no demostraron surtir efectos que pudieran reflejarse sobre los rendimientos y contenido de proteína del Kudzu.

\section{LITERATURE CITED}

1. Roberts, R. C. and party, Soil Survey of Puerto Rico, U.S.D.A. Series 1936, No. 9 Bur. of Plant Ind. in cooperation with Univ. P. R. Agric. Exp. Sta., 1942.

2. Riera, A. R., Laboratory recommendation of lime to an acid soil checks with expected pH changes, J. Agr. Univ. P. R. 30 184-5 1946.

3. Samuels, G., and Landrau, P., Jr., The effects of fertilizer applications on the yields and nodulation of tropical kudzu, Soil Sci. Soc. of Amer. 16 154-5 April 1952.

4. Smith, R. M. and Chandler, J. V., Tropical kudzu moves into Puerto Rico, Crops and Soils, pp. 12-14, March 1951.

5. Telford, E. A., and Childers, W. F., Federal Expt. Sta. in Puerto Rico, U.S.D.A. Office of Expt. Sta. Cir. No. 67, 1947. 